Rapp. Grønlands geol. Unders. 99, 89-98 (1980)

\title{
THE NORTH GREENLAND FOLD BELT IN EASTERN JOHANNES V. JENSEN LAND
}

\author{
N. J. Soper, A. K. Higgins and J. D. Friderichsen
}

This report concerns that part of the North Greenland fold belt in north Peary Land (Johannes V. Jensen Land) which lies east of Polkorridoren (the glacier filled depression between Frigg Fjord and Sands Fjord) and north of the Harder Fjord fault (fig. 40). The rocks forming the fold belt are mainly Lower Palaeozoic quartzites, carbonates, arkoses and shales, which are an extension of the Hazen Trough that stretched through the Queen Elizabeth Islands of Canada and across northern Greenland. Because of the northward increase in deformation and metamorphic grade, it is convenient to subdivide the region into a southerly, less deformed, area in which a stratigraphical sequence can be established, and a northerly area in which only lithological units can be mapped. The dividing line corresponds to that, north of which, 'way-up' criteria cannot be used owing to the masking of the sedimentation structures by a pervasive schistosity. This line runs approximately from the northern end of Paradisfjeld to Bliss Bugt.

Brief observations on rocks in three other areas are given: the Harder Fjord fault zone (fig. 40), a line of intrusive centres south of the Harder Fjord fault (fig. 41), and volcanic rocks of the Kap Washington Group $80 \mathrm{~km}$ west of Sands Fjord.

\section{Southern area - stratigraphy}

North of the Harder Fjord fault the threefold subdivision of the rocks of the Polkorridoren area erected in 1969 (Dawes \& Soper, 1973, 1979) has been verified. The units have been traced eastwards, and a new unnamed quartzite group found beneath the previously known lowest group (fig. 40).

\section{$O$ - Unnamed quartzite group}

About $10 \mathrm{~km}$ south-west of Kap Ole Chiewitz, a sequence of massively bedded quartzites was found underlying the carbonates of the Paradisfjeld Group. The sequence, which includes a few shale and calcareous beds, is several hundred metres thick. It is strongly folded, and occurs in the core of a major anticline (fig. 40).

\section{1 - Paradisfjeld Group}

In the type area south of Sands Fjord (fig. 40) this group consists of strongly deformed, yellow and grey carbonate rocks and calc-phyllites. Three further developments of carbonate rocks similar in character have been found; two of them pass transitionally upwards into the Polkorridoren Group, while the third development is isolated. All are equated with the Paradisfjeld Group. 


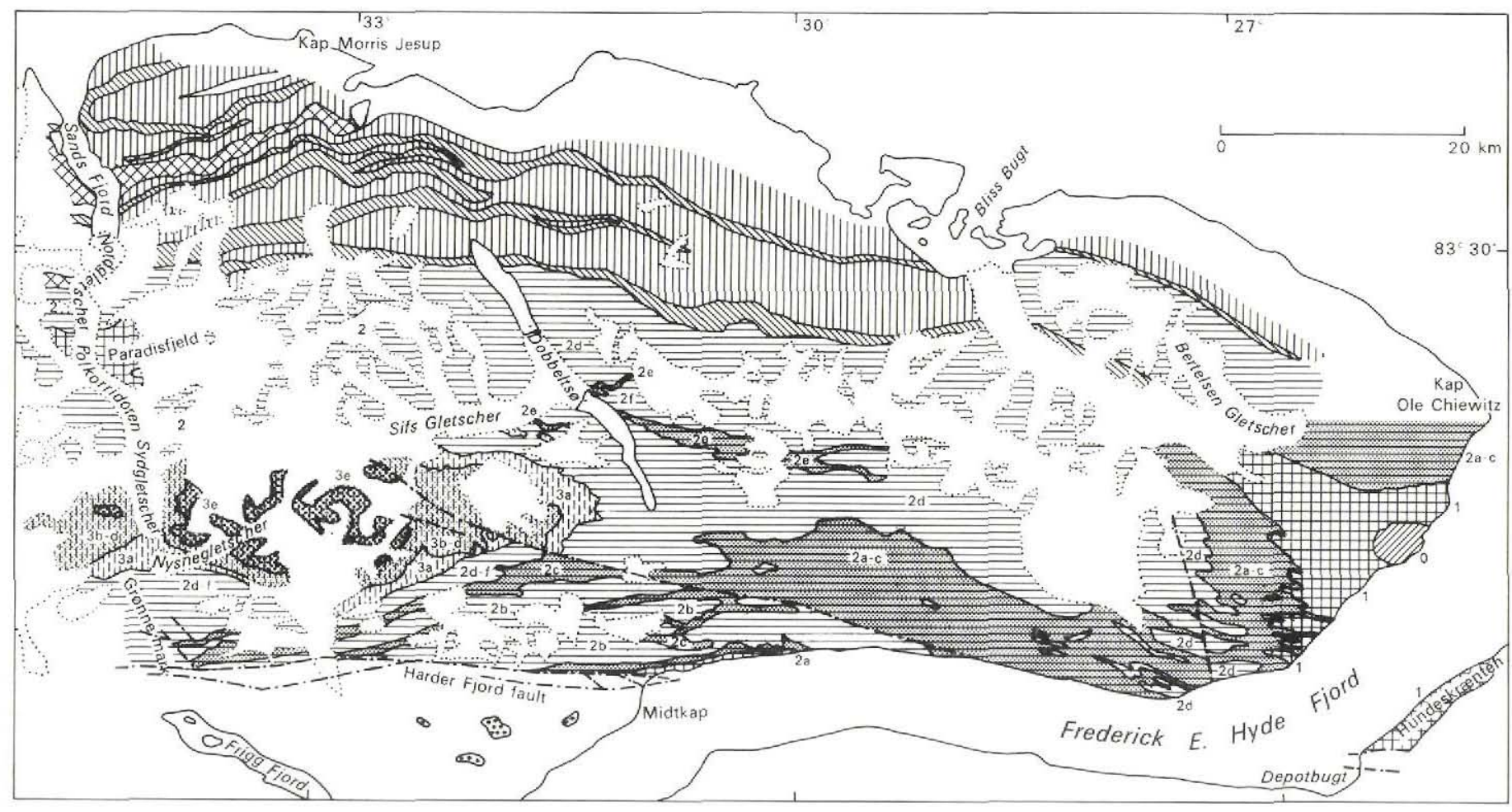

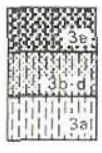

Sydgletscher Group

Fig. 40. Geological map of eastern Johannes $\mathrm{V}$. Jensen Land.

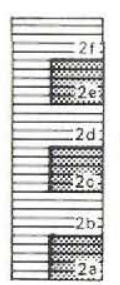

Carbonate/marble
Phyllite/shale/schist
Psammite/flysch
Volcanic centres 
The first development occurs in the east of the region, outcropping between the nose of Bertelsen Gletscher and Frederick E. Hyde Fjord (fig. 40). Although strongly folded and cleaved the rocks retain more of their original sedimentary characteristics than those in the type area. Three mapping divisions have been recognised locally: (a) a lower, dark grey-weathering sequence of massive limestones with fragmental textures, interbedded with calcareous shales; (b) a sequence of massively bedded, white, black, orange and grey limestones, occasional sandy limestones and a few breccia or conglomerate beds; (c) an upper sequence of thinly laminated, orange- or yellow-weathering carbonates, commonly showing cross-bedding, interbedded with calcareous shales and conspicuous breccia or conglomerate beds. The latter are conspicuous only in the upper sequence, and range from about $10 \mathrm{~cm}$ to more than $4 \mathrm{~m}$ in thickness. They consist of angular, often rectangular, fragments of yellow, grey and black carbonates or carbonate-mudstone, rarely black chert fragments, in a carbonate matrix. The largest fragment seen was of grey limestone and measured $180 \mathrm{~cm}$ in its longest dimension. The carbonates pass conformably upwards into the flysch sequence of the Polkorridoren Group (2a: fig. 40).

The second development of calcareous rocks, underlying the main flysch sequence and equated with the Paradisfjeld Group, occurs farther west, on the north side of Frederick E. Hyde Fjord east of Midtkap (fig. 40). This sequence also consists of massive, yellow- and dark grey-weathering carbonates, commonly exhibiting fragmental, and sometimes oolitic textures. They are interbedded with calcareous shales. A thin bed of limestone conglomerate with quartz arenite matrix is found in the transition zone with the overlying shales and siltstones of the Polkorridoren Group.

The third isolated development of grey- and orange-weathering carbonates outcrops in the cliffs of Hundeskrænten on the south side of Frederick E. Hyde Fjord (fig. 40). The carbonates are strongly folded so that parts of the sequence are repeated along the $15 \mathrm{~km}$ cliff section. No upper or lower limits to the carbonates were observed. Soper \& Dawes (1979) suggested comparison with the Paradisfjeld Group; correlation seems certain now that Paradisfjeld Group carbonates are known on the north side of Frederick E. Hyde Fjord only $10 \mathrm{~km}$ away and are approximately on strike.

The only body fossils so far recovered from the carbonate developments are fragments of inarticulate brachiopods, from the sequence east of Midtkap. These suggest that the sequence is Lower Palaeozoic rather than Precambrian (J. Peel, personal communication).

\section{2 - Polkorridoren Group}

This, the main flysch sequence of the fold belt, is exposed over large areas, and forms most of the higher mountains. It consists largely of arkosic sandstones interbedded with variable amounts of shale. The best development of the sequence is found in the area between 'Dobbeltsø' and Frederick E. Hyde Fjord where it has been possible to recognise a sixfold internal subdivision (2a-f: fig. 40). The total thickness is at least $2000 \mathrm{~m}$.

$2 a$ A poorly exposed, recessive unit of black shales with thin psammite beds overlies the carbonates of the Paradisfjeld Group, east of Midtkap. The upper contact with $2 \mathrm{~b}$ is transitional, where an alternation of dark shale and psammite units about $20 \mathrm{~m}$ thick, gives way to massive, thick-bedded turbidite units. Samples of the shales collected for micropalaeontological studies have yielded a single identifiable acritarch which is "not Precambrian" (C. Downie, personal communication). 
$2 b$ This is the first of three divisions of brown-weathering arkosic flysch (see also $2 \mathrm{~d}$ and $2 \mathrm{f}$ ). Graded sandstone beds are typically more than $1 \mathrm{~m}$ thick, and in many places have erosional bases and flute casts. They fine upwards from conglomerate with $1 \mathrm{~cm}$ size quartz and feldspar clasts in about equal proportions, to fine sandstone with no internal bedding structures, into thin ripple laminated siltstones. Mudflake conglomerates are often seen, and rounded siltstone nodules are randomly distributed in somè beds.

$2 c$ This is a major mudstone-siltstone unit, with a characteristic green- and purple-weathering colour, which forms an excellent mapping unit. The thickness is unknown because of strong deformation; in the mudstones cleavage is the dominant fabric. The siltstone layers are, characteristically, a few centimetres in thickness and commonly exhibit linguoid ripples. Within the sequence, a number of thick arkosic beds occur, similar to those of the flysch units above and below. Trace fossils are locally abundant near the $2 b / 2 c$ contact.

$2 d$ This is a thick development of brown-weathering arkosic flysch. South of 'Dobbeltsø' the lowest beds are two massive arkosic units whose detailed characteristics enable them to be followed for $10 \mathrm{~km}$ or more. Arenaceous units attain three or four metres in thickness, and in places are composed of amalgamated beds. Impersistent blue slates occur at several levels.

$2 e$ This green and purple shale unit shows greater lateral and vertical variation in thickness and lithology than $2 c$, and contains a greater proportion of arenaceous beds. Eastwards from 'Dobbeltsø' it thickens, first to include flinty silicified beds and thin carbonates, then it develops an increasing proportion of arkosic sandstones until its distinctive characters are lost.

$2 f$ This is the highest unit of brown-weathering arkosic flysch, and is similar in character to $2 \mathrm{~b}$ and $2 \mathrm{~d}$. It passes upwards into the lowest formation of the Sydgletscher Group.

Traced westwards from the area of best development north of Midtkap, formations 2a, 2c and $2 \mathrm{e}$ thin and may die out completely. They are not developed in a comparable facies in the Grønnemark area where, however, the base of the Polkorridoren Group is not seen. Traced eastwards, units $2 a, 2 b$ and $2 c$ merge, largely by reduction of thickness of the $2 b$ arenaceous beds and loss of the distinctive coloration of the $2 \mathrm{c}$ siltstones and mudstones. In the extreme east, south of Bertelsen Gletscher, formations $2 \mathrm{a}-\mathrm{c}$ are represented by a thick development of mainly black-, grey- and orange-weathering mudstones and siltstones, which lie between Paradisfjeld Group carbonates and thick arkosic turbidites of $2 \mathrm{~d}$. Interbedded dark blue mudstones and thin, buff, ripple-laminated siltstones are commonly found in this part of the sequence, together with a few black, carbonate horizons and coarse arenites with a black, carbonate matrix.

\section{3 - Sydgletscher Group}

This group contains a more varied suite of sediments than the underlying Polkorridoren Group, and includes sandstones with a calcareous matrix, calcareous shales and thin carbonates. Its outcrop has been traced eastwards from the type area around Sydgletscher (fig. 40), almost as far as 'Dobbeltsø' and south of Sifs Gletscher where it terminates. No further representatives have been identified. The main divisions (3a-e) erected in 1969 (Dawes \& Soper, 1973), have been retained for the present. 
$3 a$ Nysne Gletcher mudstones. This division consists of purple, green and grey mudstones and siltstones, which are similar in character to the mudstone units within the Polkorridoren Group.

$3 b$ Lower Sydgletscher shales. This is a varied sequence of dark shales, carbonates and siltstones. Thinly laminated, yellow-weathering, calcareous siltstones with ripples are the commonest lithology. West of Sydgletscher the sequence is about $350 \mathrm{~m}$ thick.

3c Sydgletscher quartzite. Around Sydgletscher this division consists of two units of silicified thin-bedded quartz siltstone separated by shales, and is easily recognisable. It thickens from south to north to a maximum of about $200 \mathrm{~m}$.

$3 d$ Upper Sydgletscher shales. This is a generally upward coarsening sequence of dark blue shales, which are sometimes calcareous, interbedded with thin carbonate beds and near the top thin arenaceous beds. West of Sydgletscher it is about $150 \mathrm{~m}$ thick. Hurst \& Surlyk (this report) collected a poorly preserved graptolite assemblage, probably of lower Llandovery age, from this unit.

$3 e$ Sydgletscher sandstone. This division is at least $500 \mathrm{~m}$ thick, though the top is not exposed. It consists of thick beds (up to $5 \mathrm{~m}$ ) of buff-weathering, micaceous sandstones without internal structures, interbedded with laminated, dark siltstones. Dawes \& Soper (1973) reported unidentifiable graptolite remains from the lower part.

\section{Northern area - lithology}

North of a line from Paradisfjeld to Bliss Bugt, primary bedding is rarely discernable and the dominant schistosity is the penetrative $S_{2}$ cleavage. A low to medium grade metamorphism accompanies the increase in deformation intensity. Throughout the region, many E-W trending lithological units may be traced for tens of kilometres, though in the absence of 'way-up' criteria no stratigraphical sequence can be established, and any correlation with the succession farther south is speculative. The lithological units recognised correspond to those of Fränkl (1955): the Kap Morris Jesup quartz phyllites, Ulvebakkerne marbles, Sands Fjord quartz phyllites, Nunatak quartzitic slates and Sortevæg marbles and phyllites.

In this northern area, psammitic, flyschoid sequences are common, and make up E-W trending ridges. Some of these sequences certainly are equivalents of the Polkorridoren Group, but others may correspond to different stratigraphical levels. Interbedded shales have been transformed into muscovite-, biotite- or chlorite-phyllites, and in some cases muscovite-garnet schists.

Carbonate rocks are conspicuous east of Sands Fjord in an E-W trending, easily mapped belt. These are the Ulvebakkerne Marbles of Fränkl (1955). They comprise pale grey- or yellow-weathering, medium to coarse-grained marbles, which preserve original banding severely contorted by two or three interfering fold phases. The marbles occur as scarp-forming units, up to $100 \mathrm{~m}$ thick, interbedded with recessive quartz-muscovite phyllites or psammites. It is thought that the main belt of carbonate rocks could be equivalent to the Paradisfjeld Group, but the position of subsidiary developments of carbonates at other levels is uncertain.

In the northernmost mapped area, between Sands Fjord and Kap Morris Jesup (fig. 40), a variety of rock units were found. These include black and grey quartzites, brown quartzitic 
sandstones, and muscovite-, biotite- and garnet-bearing schists. Chlorite is common, but it is not certain whether this is progressive or retrogressive. Magnetite phenocrysts are common and conspicuous at certain levels.

\section{Structures}

In the area mapped north of the Harder Fjord fault (fig. 40), the chronology established in 1969 by Dawes \& Soper (1973) of three main coaxial fold-producing phases of deformation has held. South of the fault there appear to be additional complexities (Pedersen, this report). The area described here corresponds to the structural-metamorphic zones 3, 4 and 5 of Dawes \& Soper $(1973,1979)$.

Major $F_{1}$ fold structures dominate in the southern part of the fold belt. On a regional scale they are, no doubt, chiefly responsible for the preservation of the Sydgletscher Group in a synclinal structure, and the Paradisfjeld Group in anticlinal structures in the type area and south-west of Kap Ole Chiewitz. They are usually upright E-W trending, major folds, which in the extreme east swing to NW-SE trends. They may be slightly overturned either northwards or southwards. $S_{1}$ cleavage is locally developed in shaley lithologies.

$F_{2}$ folds occur throughout the fold belt. In the south the $S_{2}$ cleavage is superimposed on $F_{1}$ structures, and occurs in all but the most massive rock types. In the north $S_{2}$ becomes progressively more pervasive so that bedding and way-up criteria are lost, and $S_{2}$ is the dominant schistosity. In the south $F_{2}$ folds tend to be more open than $F_{1}$ structures, with, in places, rather angular chevron-type hinge zones. They are generally seen as northerly verging, medium-scale folds with south dipping, moderately inclined axial planes. In a broad zone along the north margin of Frederick E. Hyde Fjord, north of the Harder Fjord fault, the $S_{2}$ cleavage flattens out and even dips northwards at shallow angles. This has given rise to the somewhat anomalous appearance of well developed neutral folds in the Paradisfjeld Group carbonates and Polkorridoren Group flysch, in coastal cliffs east of Midtkap. The change in orientation of $S_{2}$ may be related to distortion along the line of the Harder-Fjord fault.

$F_{3}$ structures are confined to the northern area of the fold belt, and become increasingly important northwards. These structures occur mainly on a minor scale, as a spaced crenulation cleavage superimposed across the dominant $S_{2}$ schistosity. In the Sands Fjord area a few major, probable $F_{3}$, structures have been identified. The $S_{3}$ fabric dips southwards at high to moderate angles.

\section{Harder Fjord fault zone}

This E-W trending fault zone separates the strongly deformed and cleaved rocks of the fold belt from the relatively less deformed and non-metamorphic strata to the south. In the three areas where examined it consists of a network of faults, with the intervening zone occupied by rocks not readily correlateable with the sequences to the north and south. A long and complex history of movement is envisaged for this major crustal dislocation.

Depotbugt. North of the fault zone, (probable) Paradisfjeld Group carbonates outcrop extensively at Hundeskrænten. Within the fault zone north-east of Depotbugt (fig. 40) occur white quartzites, chert conglomerates with a quartzitic matrix, red polymict conglomerates 
and carbonaceous siltstones and shales. Thick dolerite dykes and sills intrude the sequences, and both sedimentary rocks and dolerites are brecciated along the fault lines. The lithologies probably belong to several sequences of different ages. Shale samples, collected by P. R. Dawes and N. J. Soper in 1969 at a different locality in the fault zone, south-east of Depotbugt, contain angiospermous pollen grains of Tertiary age (C. Croxton et al., GGU internal report, 1980).

North of Midtkap. There are two major faults in the area (fig. 41). The southern one is associated with several dolerite dykes, and locally a thick sill runs close to the northern fault. To the north, Paradisfjeld Group carbonates wedge out westwards along the northern fault. South of the southern fault, purple and green Frigg Fjord mudstones and thin bedded turbidites crop out extensively. Cropping out between the faults is a several hundred metres thick sequence of conglomerates, sandstones and carbonaceous (coaly) shales; hematite nodules are common. This sequence has yielded well preserved plant fossils of Upper Permian age (R. H. Wagner, personal communication), and fragments of tree trunks of up to $40 \mathrm{~cm}$ in diameter and $120 \mathrm{~cm}$ in length. South of this sequence and adjacent to the southern fault, there is a massive unit of greenstones, which preserves clear pillow structures representing a subaqueous extrusive episode. Greenstone units, lacking pillow structures and often severely brecciated, occur within the fault zone as scattered outcrops over an east-west distance of about $10 \mathrm{~km}$. Their age is unknown. Acid and basic intrusive rocks, reported from the fault zone in this area by Dawes \& Soper (1979), are probably related to the line of intrusive centres south of the fault described below.

East of Grønnemark. A sequence of sediments occurs in the fault zone east of Grønnemark. The rocks are faulted and folded, but some of the fold structures are unlike structures seen in the fold belt to the north, and were probably produced, or modified, during fault movements. The lowest rock unit is a finely-banded, black and yellow, cross-bedded siltstone and dolomite rock, with local limestone and sandstone horizons. The higher units are all carbonate-poor and consist of black chert, white quartzite with thin conglomerates, chert and quartzite conglomerates of variable thickness with sandy matrix, black shale and siltstone with carbonate inclusions, and finally a thick, competent and massive, brown-weathering, micaceous calc-sandstone. The lowest unit has yielded the bivalve Inoceramus, which suggests a possible Cretaceous age for part of the sequence. The apparent succession may be disturbed by faulting, however, and consist of several sequences of different ages.

\section{Intrusive centres south of the Harder Fjord fault}

A line of small intrusions and volcanic centres extends westwards from Midtkap, approximately parallel to the Harder Fjord fault, but $3-8 \mathrm{~km}$ south of it (fig. 41 ). They may be related to small acid and basic intrusions in the fault zone north of Midtkap, reported by Dawes \& Soper (1979). The more important intrusions are designated A-F on fig. 41. Intrusion A, composed of serpentinite and minor bodies of granodiorite and diorite, is described by Pedersen (this report), together with a small gabbro body on the west side of Frigg Fjord, west of the limits of fig. 41. 


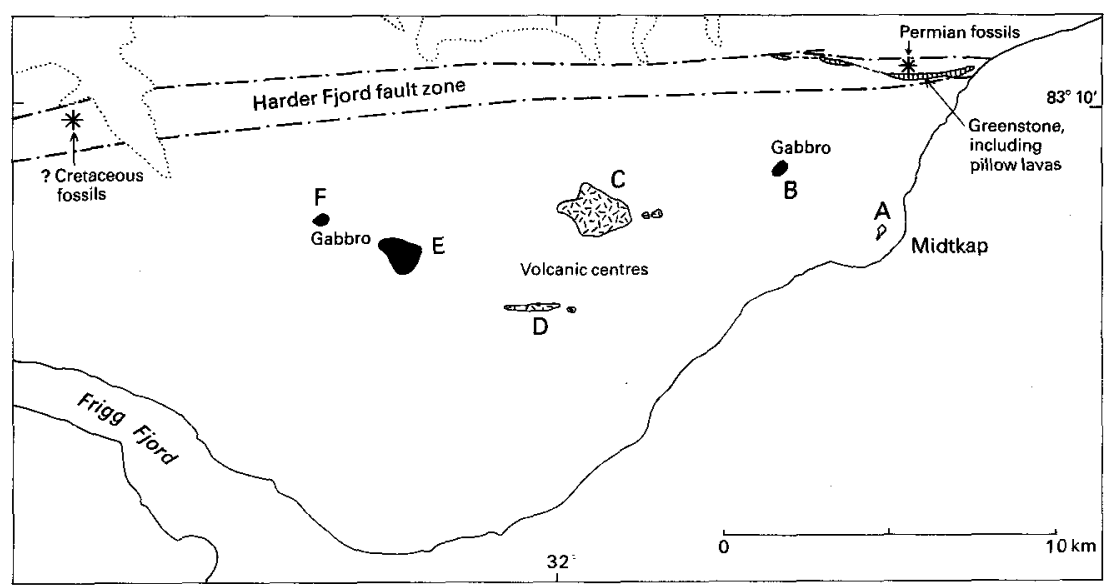

Fig. 41. The intrusive centres south of the Harder Fjord fault, labelled A-F.

Intrusion B consists of an elliptical outcrop of gabbro, about $500 \mathrm{~m}$ in its longest dimension, with an arcuate margin of serpentinite on its south-west side. A zone of carbonate metasomatism, associated with small serpentinite intrusions, surrounds the gabbro, particularly to the west and south. A number of minor serpentinite bodies and breccia-filled necks occur between intrusions $\mathrm{B}$ and $\mathrm{C}$.

Intrusion $\mathrm{C}$, situated about $10 \mathrm{~km}$ due west of Midtkap, apparently represents the neck of a large volcano. It measures approximately $2 \mathrm{~km}$ in diameter. The principle rock types are serpentinite and agglomerate, the latter formed, in part, by brecciated lava and lava breccia in a lava matrix, but most notably, by exotic blocks of up to hundreds of metres in size. The principal exotic blocks are of amphibolite gneiss, but acid gneiss, garnet-mica schist, hornblende granite and non-metamorphic sediments are also present. All are extensively brecciated and partially assimilated, and commonly veined by carbonate. If the gneiss blocks represent the basement beneath the fold belt, two important conclusions may be drawn: the Palaeozoic depositional basin was evidently ensialic, even if located close to a continental margin, and the basement rocks were in amphibolite facies at the levels represented by the exotic blocks. This volcanic centre is surrounded, particularly to the east and south, by a zone of brecciation, carbonate metasomatism and minor serpentinite intrusions. There are two small breccia bodies to the east, presumably representing satellite necks. No trace of the superstructure of this volcano remains at the present erosion level, but it is likely to have been very extensive.

Intrusion $\mathrm{D}$ consists of several bodies of serpentinite and breccia. The breccia fragments are of brown or grey fine-grained basalt in a matrix of the same material. The neck-like bodies form prominent crags (fig. 42).

Intrusions $E$ and $F$ are situated about $18 \mathrm{~km}$ west of Midtkap and $8 \mathrm{~km}$ north-east of Frigg Fjord. Intrusion $\mathrm{E}$ includes gabbro, leucogabbro, serpentinite and breccia. Intrusion $\mathrm{F}$ is a small gabbro body forming a conical, craggy hilltop.

This group of intrusions is of unknown age and most have been visited only on helicopter 
Fig. 42. Volcanic neck forming part of intrusive centre D.

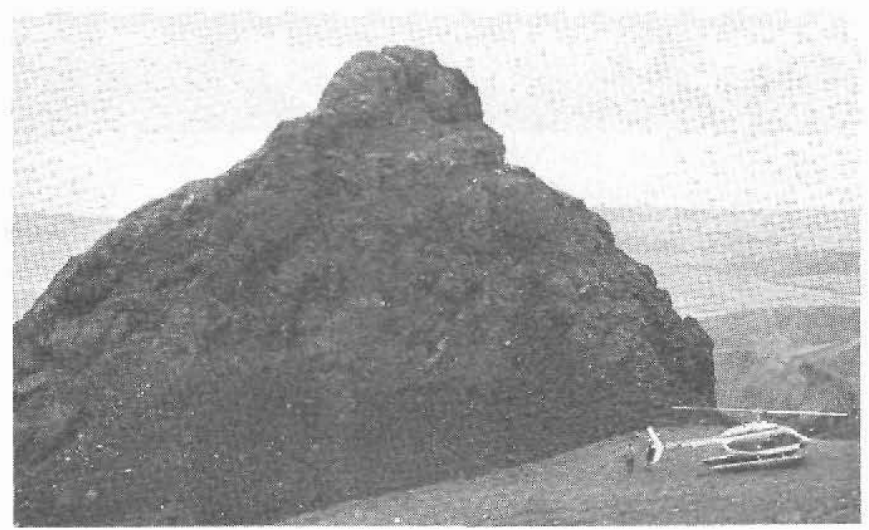

reconnaissance. An understanding of their origin and mode of emplacement should throw light on the geotectonic history of the Harder Fjord fault, with which they seem to be spatially associated.

\section{Kap Washington Group}

The Kap Washington Group volcanics outcrop along the northern margin of the fold belt west of the region mapped in 1979. They were examined briefly during a helicopter reconnaissance trip which extended as far as Lockwood $\varnothing, 100 \mathrm{~km}$ west of Kap Morris Jesup (fig. 1).

An impressive section is exposed on the western coast of Lockwood $\varnothing$, in which numerous levels of pale limestones occur, apparently interbedded with the volcanic rocks. The stratigraphical relationships require careful study since the fossils in the limestones (principally bryozoans) suggest a (?) Permian age (E. Håkansson, personal communication). This contrasts with the assumed Cretaceous-Tertiary age for the Kap Washington Group (Dawes, 1976), which was supported by a Rb-Sr isochron study giving an age of $c$. 63 m.y. by Larsen et al. (1978), on rhyolitic lavas collected south of Kap Washington.

The volcanics are a complex suite. Parts of the sequence are monotonous, bedded basic volcanics, but rhyolites seem common, as do spectacular green and red agglomeratic tuffs which suggest the near presence of volcanic vents.

The south margin of the volcanic sequence is the Kap Cannon thrust (Dawes, 1976), which is marked by extensive mylonite developments, and locally, in the near vicinity of the thrust, also by large scale folding.

\section{References}

Dawes, P. R. 1976: Precambrian to Tertiary of northern Greenland. In Escher, A. \& Watt, W. S. (edit.) Geology of Greenland, 248-303. Copenhagen: Geol. Surv. Greenland.

Dawes, P. R. \& Soper, N. J. 1973: Pre-Quaternary history of North Greenland. In Pitcher, M. G. (edit.) Arctic Geology. Mem. Amer. Assoc. Petrol. Geol. 19, 117-134. 
Dawes, P. R. \& Soper, N. J. 1979: Structural and stratigraphic framework of the North Greenland fold belt in Johannes V. Jensen Land. Peary Land, Rapp. Grønlands geol. Unders. 93, 40 pp.

Fränkl, E. 1955: Rapport über die Durchquerung von Nord Peary Land (Nordgrönland) im Sommer 1953. Meddr Gronland 103(8), 61 pp.

Larsen, O., Dawes, P. R. \& Soper, N. J. 1978: Rb/Sr age of the Kap Washington Group, Peary Land, North Greenland, and its geotectonic implication. Rapp. Grønlands geol. Unders. 90, 115-119. 